\title{
ETHICAL FACTORS IN SPATIAL ENVIRONMENT
}

\author{
Piotr Winskowski \\ Chair of Environmental Architecture, Cracow University of Technology, \\ Warszawska st. 24, PL 31-155 Cracow, Poland. Phone: +4812 6282497
}

Submitted 14 Dec 2006

\begin{abstract}
The paper consists of a review of the methods of emphasizing values in spatial environment seen in the public art of the second half of the $20^{\text {th }}$ century. The most influential factors - the disputable status of arts between non-artistic sphere, the evolution of abstract art (both in the sense of the geometric shapes of pieces and the conceptual potential of its idea), the environmental perspective of contemporary art to accent the relation more than the solid piece - are regarded. Polish examples of Second World War memorials (Westerplatte, Gdańsk, Treblinka, Auschwitz-Birkenau) and later tragic events (the Gdańsk 1970 monument) as well as foreign ones (the Walter Benjamin memorial in Portbou, Spain) are discussed in relation to the above problems. The role of the accidental factors of commemoralized events and non-artistic aspects of its memorial's perception are emphasized. They are seen as important keys for the reconstruction of the past existential situation in the mind and body of the contemporary perceiver / interactor. In this way the relationship between a past event and the present perception is formed in a very deep, intimate way. This strategy of using spatial medium for emphasizing an ethical message is also recognized in a contemporary, temporal installation (Helsinki 2000) as some proof of its present character and a wide potential for future public art.
\end{abstract}

Keywords: public space, spatial environment, public art, artistic installations, memorials, ethical message.

\section{Introduction}

The paper consists of a review of the methods of emphasizing values within spatial environment as seen in public art of the second half of the $20^{\text {th }}$ century.

The term "public art" has a very broad meaning today. Happenings, other artistic performances, temporal arrangements of open city spaces and building interiors explore many potential ways of empasizing the artistic expression within this "public" field. The architect should mention here architecture itself. The stylistic features of buildings, the internal rules of their composition, complex relationship between the shape (proportions, building materials, decoration) and society (builders, owners, users) emphasize in many ways the public interest. Architecture - the "mother" or "queen" of arts in the past - often consists of pieces of other artistic disciplines and also arranges them into a spatial and symbolic unity. So the following observations concern "public art" in all the above senses: happenings or events with some (often modest) spatial components, temporal arrangements and permanent buildings, mo- numents, memorials and also the complex fushion of these elements.

Today, when the boundaries of artistic disciplines are moving and, on the other hand, the status of arts is also disputable, talking about "spatial environment" without divisions for the artistic or non-artistic qualities of an individual case is seen more adequate. Another factor is the tendency to replace a piece of art by artistic / intentional relationship between the perceiver and his environment, arranged by the author or rearranged by the perceiver himself in the case of interactive art. Both pieces and relationship, formed in a material and conceptual substance, could convey a message about the ethical values incorporated in a very private sphere of the perceiver's individual life.

This intimate, personal, ethical message in past epochs was conveyed by architecture through some schematic way (the proportions of the architectural elements), by sculpture and painting (also sculpture and painting incorporated into architecture) - mainly by 
personification. In the $20^{\text {th }}$ century abstract art showed other ways of shaping art pieces and emphasizing values through arts. In the preliminary stage of the artistic avantgarde these values, mainly concerning an inner artistic, even the hermetic problems of the new qualities of visual tools, its non-mimetic character, experiments with movement, are not related to the ethical sphere.

The Second World War constitutes here an important change. The moral shock, evoked by the huge scale of Nazi crimes, recognized after the war, the banality of evil (according to Hannah Arendt), seen later during the Nurenberg Trials and the Jerusalem trial of Eichmann, generates questions about the visual representation of these crimes, the artistic explanations of its mechanisms and, mainly, the commemoration of the war victims.

The first crucial fact here was the non-heroic (in "visual" sense) death of these victims: mainly the civil victims of Nazi mass-extermination, the victims of the Holocaust, etc. Personification would show them in a situation non-acceptable from the point of view of human dignity, and counter-productive in the sense of commemoration, which needs icons / images given for the memory to coming generations.

The second fact is the gradual success of modern art, especially the ideals of the abstract shaping of spatial environment (art, architecture, sculpture, according to the above remarks). Abstract tendency accommodates a wider spectrum of ideas, according to the move from the position of the avantgarde to the mainstream. This process opens the field of the abstract (geometric in the spatial shape and conceptual in the sense of artistic, intellectual speculation) aspects of the commemorated events. The mass character of these events evoked often a grand scale of spatial arrangements, especially on their original sites.

The more cruel nature of the war on the East European front (in comparison with the West), the permanent five-year partisan war of the underground Polish Land Army against the Nazis, the planned by Nazis and partially executed mass-extermination of Jews and Slavonic nations, and connected with them Nazis decisions to localize on Polish territory large extermination camps - all these factors lead to an especially high number of war death places and a unique, tragic chance for Polish postwar art to achieve experience in the cases of commemorating them.

The parameters of the spatial environment mentioned above - rather the relationship than piece, the abstract (conceptual) method of the transformation of some features of the original, tragic events into artistic means and the abstract (often geometrical) shape of the executed piece - together with the ethical orientation of their message open up a wide field for later artistic development. The structure of relationship between an ethical message and spatial parameters, should be considered to be fruitful for examination in contemporary art.

\section{Examples}

One of the first battles of the Second World War took place at Westerplatte: the coast guard station on the Polish territory, vis a vis the harbour of the "Free City" of Gdańsk where the city government had been dominated by the Nazis since the 1930s. The Polish 7-day defense, under permanent artillery fire, resulted in the ground being full of missiles and scrapnel and a total lack of greenery at this site.

A memorial, designed by Adam Haupt, Franciszek Duszenko and H. Kitowski, was erected here in 1966. It is dedicated to the defenders of Westerplatte and to all the Polish coast guards and navy soldiers of the Second World War. There are the names of battles cut on the surface of the obelisk (Fig 1). Between the present quiet, nice park environment with trees and foot-paths and the volume of the massive, stone memorial there appears tension which recalls an extremely heavy character of the battle. This tension achieved by artistic means is, surprisingly, increased by a trite, non-artistic relic: the remains of a modest military barrack, not a bunker, a structure which was not crucial for the battle. This twostoried structure is preserved at the maximum of $40 \%$, so its impressive view is very important here. Rumpled concrete floors, openworked walls and broken beams, standing between trees, reconstruct the intensity of the battle in the viewer's imagination and enforce the effect of the memorial (Fig 2). The battle, which rumples the concrete slab as a sheet of paper (we can touch it), makes the density of fire, literally - palpable, and the commemorative message of the nieghbouring monument - more real and serious.

Newertheless, at Westerplatte the battle was hard for both sides - the seacoast defense artillery against that of the cruiser. A tragic assymetry in the battle equipment and military skills appears in another place: in the defense of a few hours of the Polish post-office in Gdańsk on September 1, 1939 with soldiers against clerks and tanks against pistols. Polish clerks, civil representatives of the Polish state in the "Free City" of Gdańsk, were killed during the battle, others imme- 


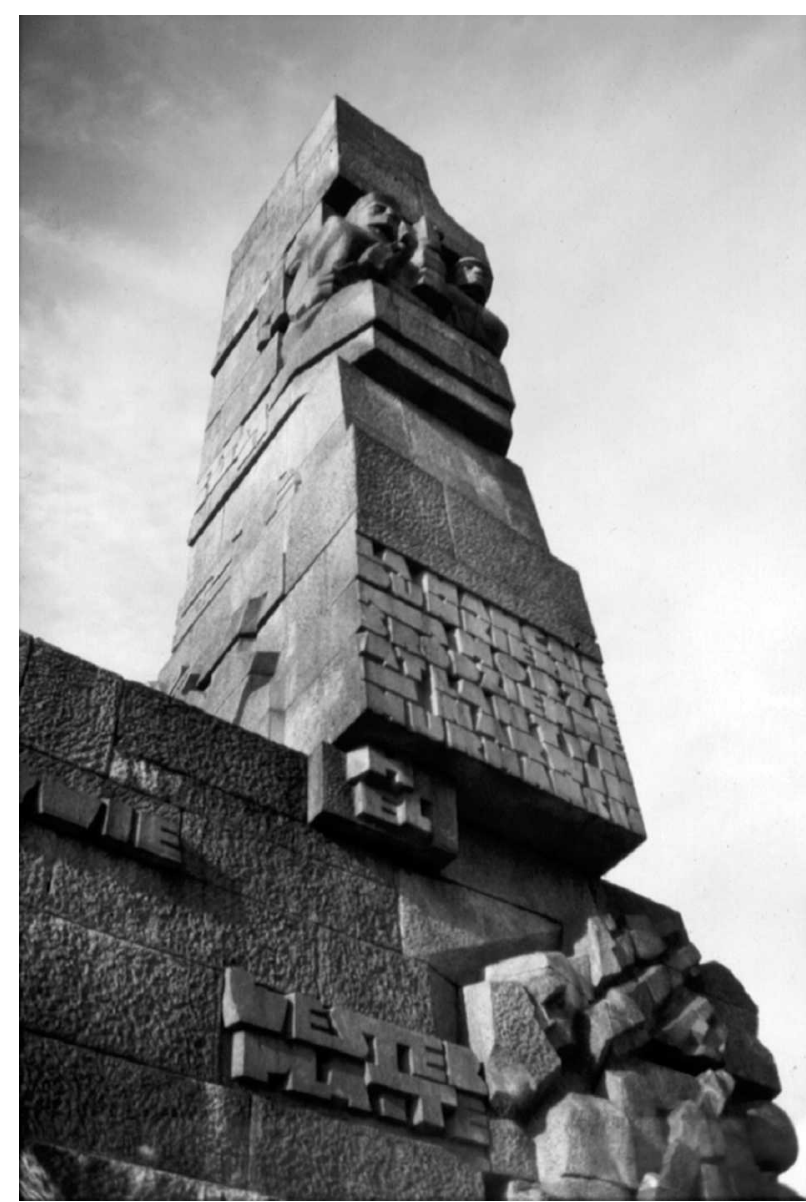

Fig 1. Adam Haupt, Franciszek Duszenko and H. Kitowski, Westerplatte Memorial, Gdańsk, 1966

diately after capitulation, others in the Stutthof Nazi extermination camp.

A monument designed by Wincenty Kuama in 1979 arranges the site of the battle in front of the post-office building [1]. Old-fashioned cobble-stones gradually change the flat square into soft flexures (Fig 3). The culmination of flexures appears in the monument, where stones are partially replaced by more and more light, stainless steel plains. In a similar style of curved forms the figure of a dying postman and some female person (Nike) are executed. Therefore, the levity of the steel plains is more interesting than the personification. They are shaped into a cloud of sheets/letters over the head of Nike, at the top of the monument (Fig 4).

Sheets of paper flying around the burnt and collapsing office buildings, and we could see these dramatic images in the TV transmissions of the World Trade Center attacks on September 11, 2001. There were no TV relations in 1939, so the artistic invention shows us the tragedy through this one, non-crucial yet impressive,

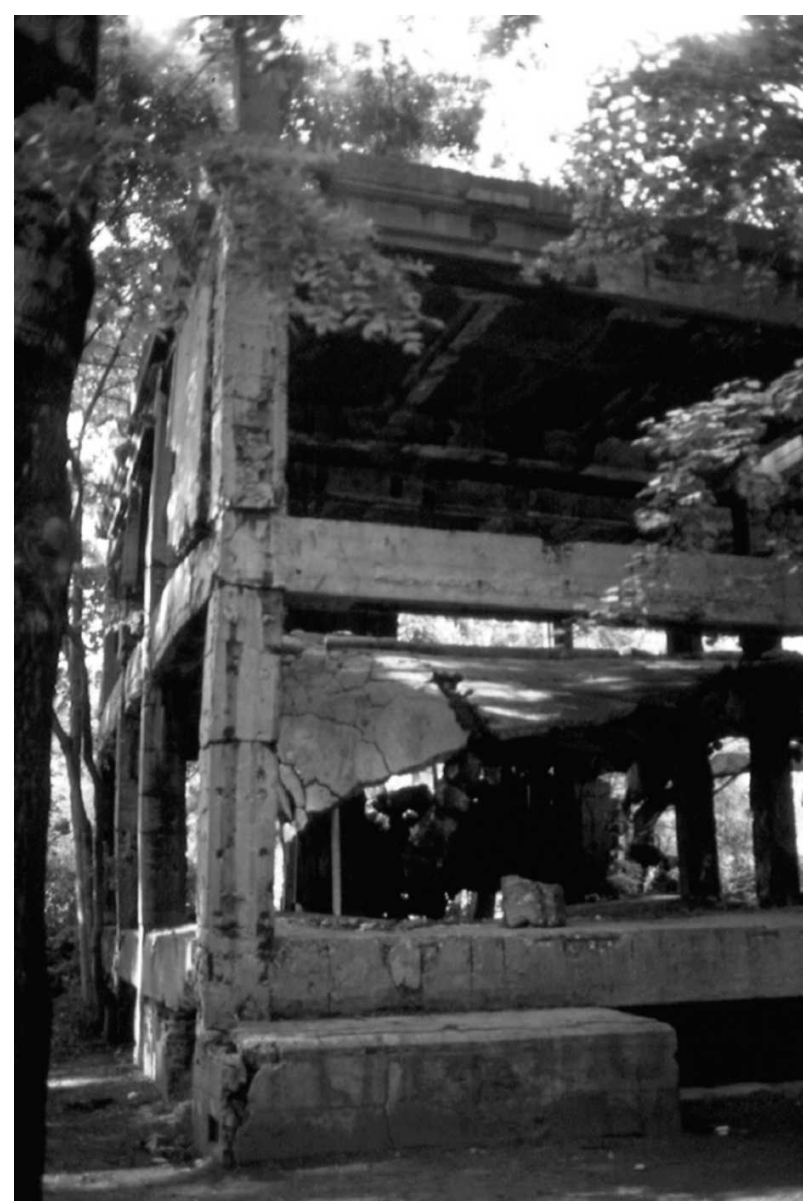

Fig 2. Ruined barrack near the Westerplatte Memorial, Gdańsk

„innocent" aspect of the commemorated event. There is a very clear and strong message about the violence, which attacks in the first step the people who work with the words written on the paper, who can send the letter with a warning and call for help. The history of burning papers, letters, books (Nazi practice in the 1930s) or crime proofs, and resistance by words of truth written and sent, are here emphasized and raised to a universal level - as a civilizational battle between barbarism and "Gutenberg galaxy".

The "Way-Monument" project by Oskar Hansen, Zofia Hansen, Jerzy Jarnuszkiewicz, Edmund Kupiecki, Julian Pałka, Lechosław Rosiński, of the second stage of the international competition of the Nazi extermination camp Auschwitz-Birkenau memorial in 1958, has achieved historical importance in Polish postwar art [2, 3]. The authors invent only one element in a large area: a wide, asphalt, diagonal way, built somewhat higher to the ground, starting at the entry to the camp, going through long rows of barraks, rows of former electri- 


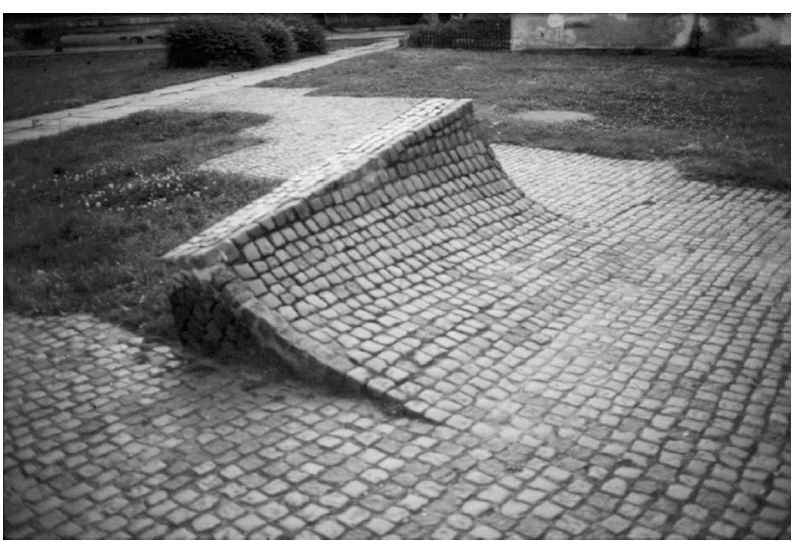

Fig 3. Contemporary arrangement of the square in front of the pre-war Polish Post-Office Building in Gdańsk

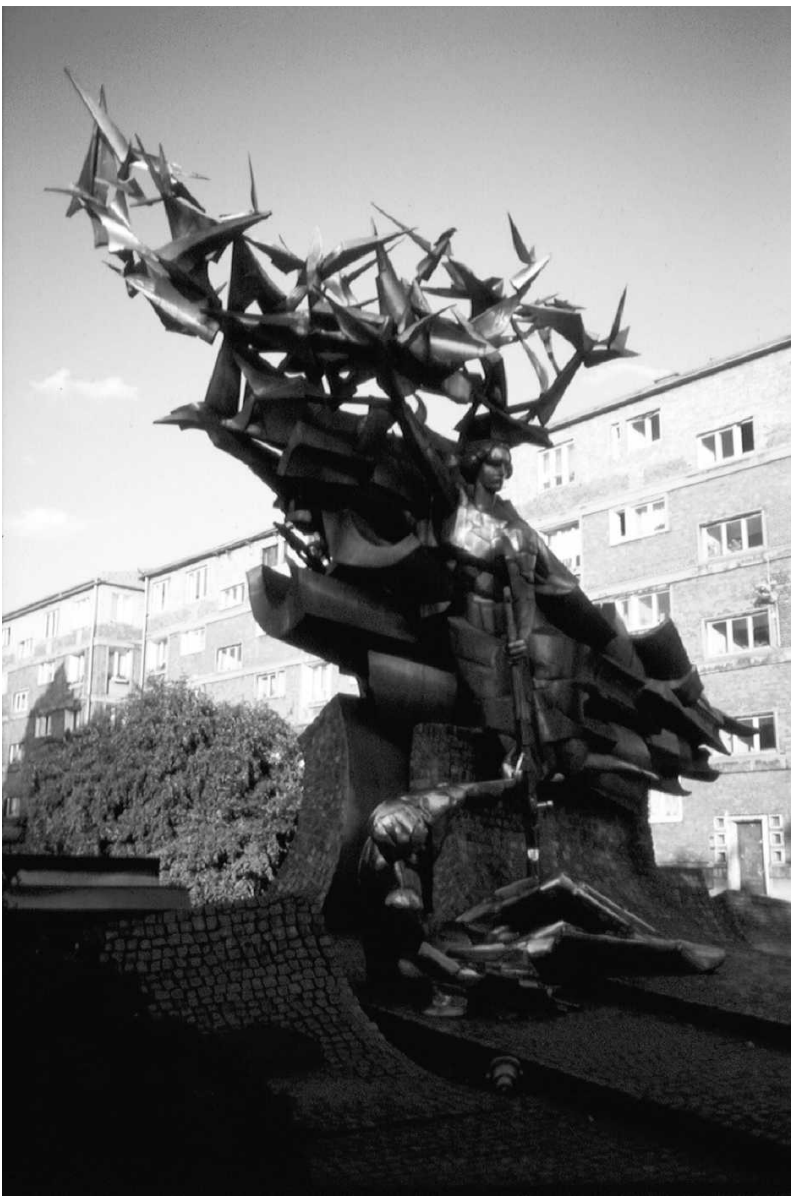

Fig 4. Wincenty Kućma, Monument of Defenders of Polish Post-Office Building in Gdańsk, 1979

city fence poles, and finishing at the ruined crematory. The camp relics placed at the area of the way would be protected on the site and surrounded by the asphalt. Viewers had to walk around them (Fig 5). The rest of the camp territory was appointed to be reclaimed by nature: trees, grass, animals from the neighbouring forest - as a "natural clock" showing the years' lapses from the time of war and life conquerning death. The minimalisation of visual elements and the length of the way, leads the visitor to intime, personal reflection - gives time and material for it; gives voice to the camp's relics, to it's size and it's invisible parts between the trees, without any additional expression of any "dramatic" sculpture.

The executed arrangement designed finally in collaboration with an Italian team (the prize ex aequo) mixes elements from both ideas, adds sculptures, texts in many languages cut in stone plates and misses the message of the most important part - the artifical way, which we can go through the former camp via a different, slanting order. Today, within the executed arrangement, we have to step directly on the ground on the same level, and in the same, ortogonal order, created by the camp's urban grid.

A visit to the place of such a strange crime is impressionable enough, independent of its spatial arrangement. Nevertheless, the quality of the silence as a space for the voices of the past, the quality of the harmony between the artificial way, designed at a slant to the criminal order of the camp, and nature, which was engaged to emphasize time - all these elements were used in the original project of the monument in the unique unity of the highest artistic interpretation of the ethical message by a spatial medium.

The Auschwitz Memorial displays the status of a relic, the crime order and procedures of industrialized killing in contrast to the contemporary, postwar order of visiting and contemplating. The same situation was discussed in the space of the Treblinka extermination camp memorial, yet without one element: any visible relics [4-6]. This camp existed since 1942, was liquidated in 1943 by the Nazis who concealed its traces under the greenery.

The author's aim for the Memorial was to reconstruct the camp area borders (also by archeological investigation methods) and later to find a visual solution for emphasizing anew our memory about the victims (mainly Jews from the Warsaw Ghetto, and from all over German-occupied). The solution proposed by Adam Haupt, Franciszek Duszenko and Franciszek Strynkiewicz and finally executed 1958-1964, is the "no man's land": the field of rocks covering the pits where human ashes were discovered. Here there is also an official, monumental stone-memorial. Nevertheless, the behavioral reaction of those who go through these stones is more impressive as an ethical message about the dreadful past of this "innocent" glade, sourroun- 
ded by forest (Fig 6). The stones slacken one's pace, make walking painful by dint of permanent stumbling, compell one to pay attention to each step. This difficult (in a physical sense) walk through a large area, when each stone reminds one of the macewa from Jewish cementeries or parts of human corpses, deformed in some macabre way, makes this way difficult also in a moral sense as obligation to memory and warning whenever human life is threatened, and the weight of past evil is realized in our minds by the durability of the stones over the fugitive ashes.

The anti-war and anti-violence accents of Polish memorials, dedicated to the victims and soldiers of the Second World War, were approved in a common agreement between society and government. Yet this did not eliminate its selective character. Memorials built in the 1950-1970s, during the communist era, could not emphasize the memory of the victims of the Soviet presence in Poland, and the crimes of the communist regime in a public space. The first memorials executed by society to commemorate victims of the regime - shipworkers killed by the police in Gdańsk and Gdynia in December 1970 - appeared in these cities at the decennial annniversary of the events, in December 1980, as an effect of the Solidarity movement. Nevertheless, the limitations of the government's "cultural policy" - the guarding memory - the spatial-environmental qualities of both these "official" and "opposition" monuments are worth analysing according to a common criterium: as a tool of ethical message. This complex message is seen, readible, and valuated positively much longer than its past patrons' political aims, and also longer than the spontaneous mobilization of society to execute its own true memorial.

The Gdańsk 1970-year memorial was invented by a shipwork engineer Bogdan Pietruszka and Wiesùaw Szyúlak, and made from stainless steel by friends of the killed workers in 1980 [7]. Three high crosses in the square at the shipwork gate were completed by realistic bas-reliefs with the scenes of workers' everyday life by Robert Pepliński and Elžbieta SzczodrowskaPeplińska.

The unity of the message about the reinforcing of faith in human and workers' rights and the memory of victims of this faith was enhanced here by a few facets of memorial detail. The first one is a continuation of the visual character of the small-scale details of the bas-reliefs in the sculptural base of the crosses where these reliefs were mounted. The second one is a circular floor arrangement around the monument, designed by

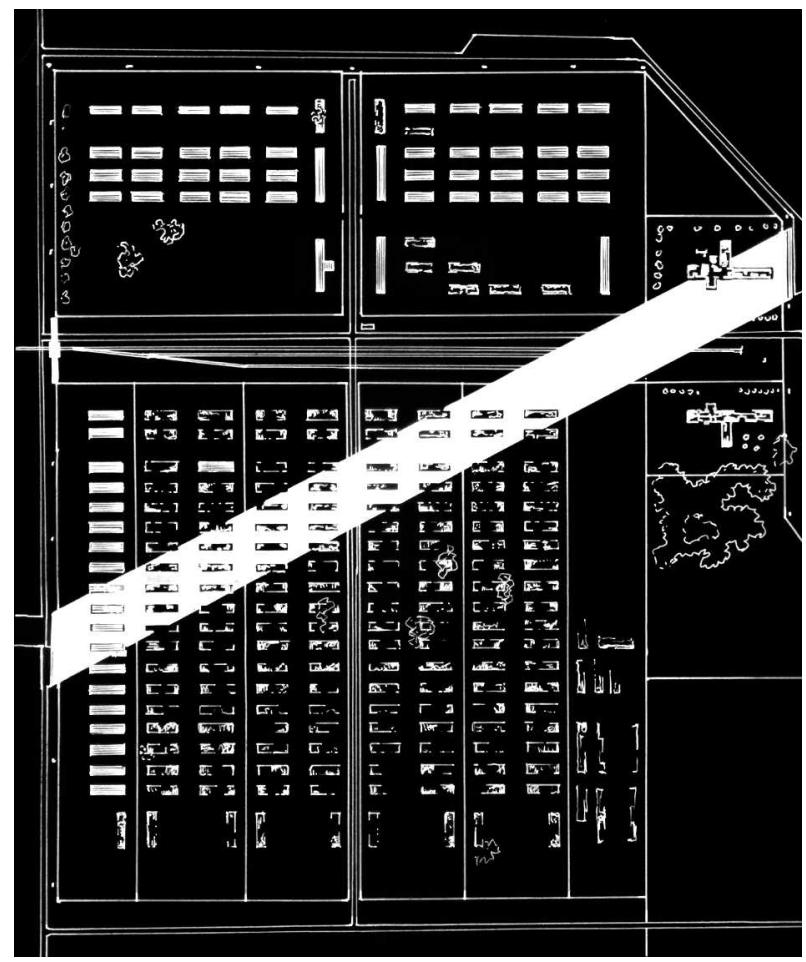

Fig 5. Oskar Hansen, Zofia Hansen, Jerzy Jarnuszkiewicz, Edmund Kupiecki, Julian Pałka, Lechosław Rosiński, Way-Monument - project of the second stage of the international competition of the Nazi extermination camp Auschwitz-Birkenau memorial, 1958. Plan

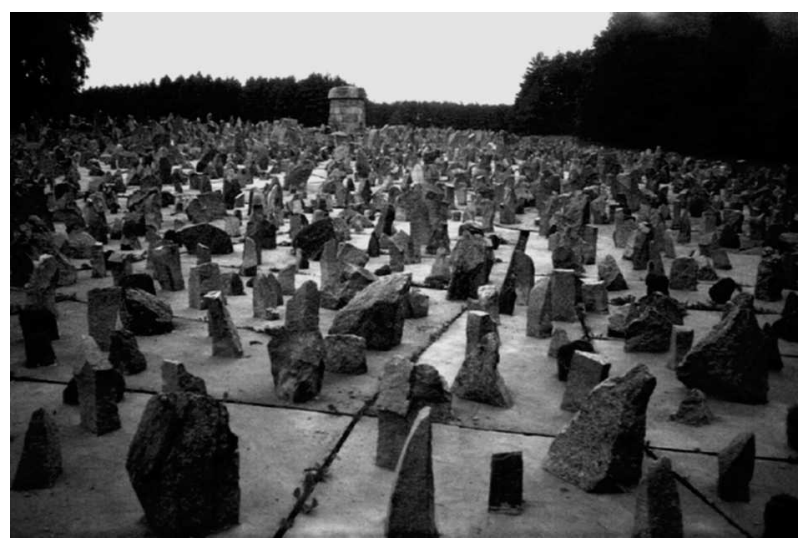

Fig 6. Adam. Haupt, Franciszek Duszenko and Franciszek Strynkiewicz, the Nazi extermination camp Treblinka memorial, 1958-1964

Jacek Krenz, Szczepan Baum and Wojciech Mokwiński, where broken cobble-stones in the middle (between the bases of the crosses) places the fire, burning symbolically from the underground. The third one is an urban character of the area, when trees, shipworks facilities and buildings are seen behind the bottom parts of the crosses, with its sculptural bases and bas-reliefs. The sky is seen behind glazed steel poles on the top of the crosses. These picturesque elements, seen together with 


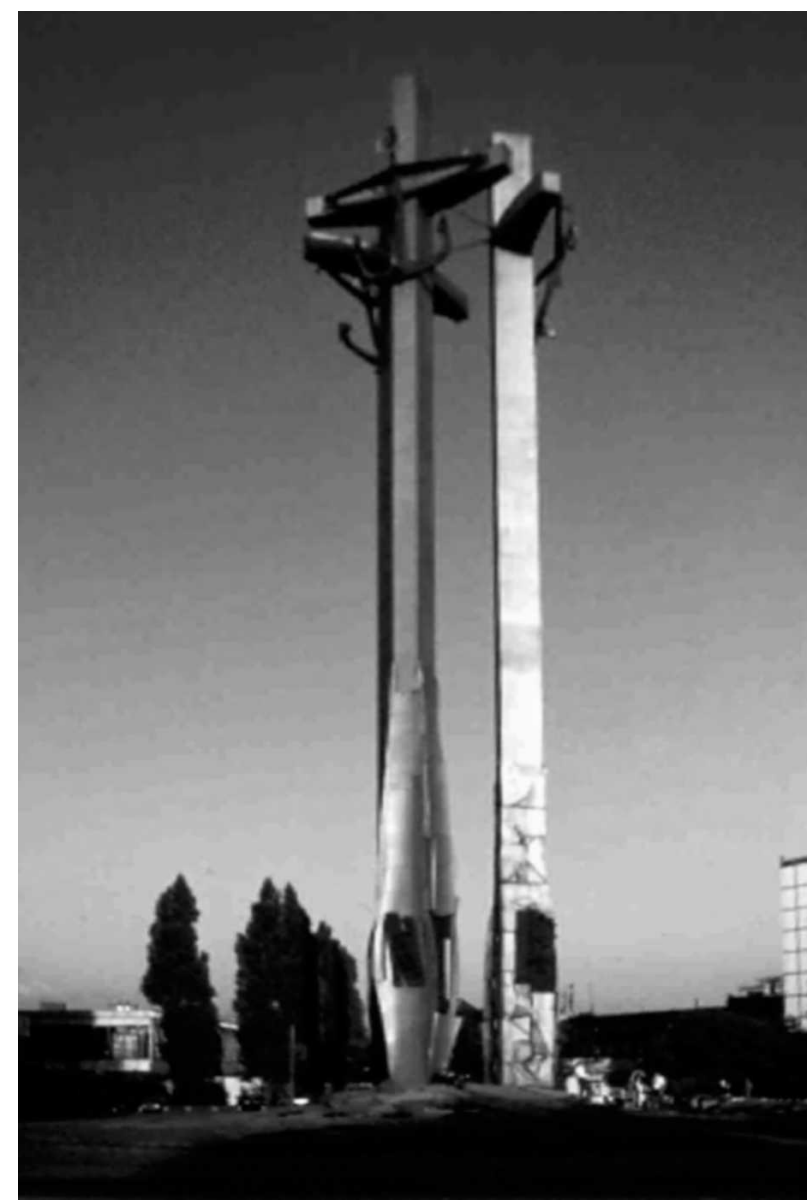

Fig 7. Bogdan Pietruszka, Wiesław Szyślak, bas-reliefs Robert Pepliński and Elżbieta Szczodrowska-Peplińska, collaboration Jacek Krenz, Szczepan Baum and Wojciech Mokwiński, Memorial to the shipworkers killed in 1970, Gdańsk, 1980

the accidental elements of the surroundings and the pure, Christian symbol of hope and victory over death, which is seen in front of the sky, emphasize a dual sense of this monument (Fig 7). The same interpretative trace shows the quotation (Psalm 29,11 in the translation of Czesław Miłosz), written on the stone wall as a part of the monument: "Pan da moc swojemu ludowi. Pan da swojemu ludowi błogostawieństwo pokoju". God's force will be done in our present life, and the benediction of peace concerns the victims of 1970 . These two levels, two addresses for the contemplation and two ethical obligations are seen parallel in both ways: by a verbal sentence and in spatial solution of the monument in its unique surroundings.

The next memorial concerns an individual person and individual tragedy. Walter Benjamin, a GermanJewish philosopher, writer and journalist, killed himself in 1940 by overdosing a morphine in Portbou - a small town in Spain on the Mediterranean coast and French

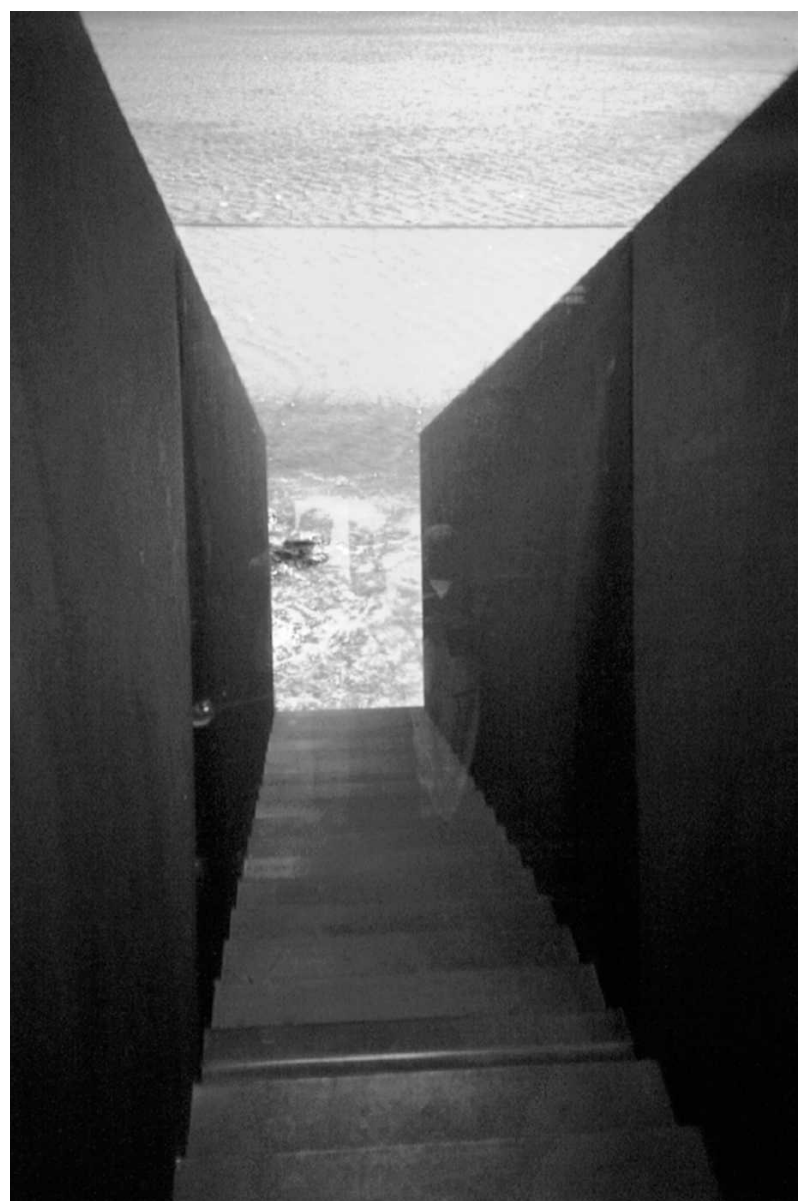

Fig 8. Dani Karavan, Walter Benjamin Memorial in Portbou, 1993. The tunnel seen towards the bottom

border - when he lost his hope of receiving a US visa to escape from the Nazis. The visa came a few days after his death. His memorial in Portbou gives an example of a gradual narration about the ethical ways of his life and death as a medium to emphasize the most subtle general message about human life, death and literature in the $20^{\text {th }}$ century architecture. The memorial was designed by a Jewish architect and artist Dani Karavan in 1993 [8-10].

Its main part is a slanting underground narrow corridor, with brown-orange clads of corten steel and a flight of stairs going down inside. A metal surface gives the effect of rumble when one descends. At the end of this passage we encounter a glass plate, protecting us from falling down into the sea and a rocky sea-coast (Fig 8). The end of the corridor ceiling is a few meters before the glass. We remain in the sunny, hot air, we equally cannot hear the rumble and sea-waves crashing against the rocks. We only see the dangerous waves, rocks, so 
we are protected by this transparent border. We don't feel the wind - often very strong at the sea cape, which we experienced before entry to the corridor. We are suddenly outside the passage, outside death (?!) in a quiet place where nothing seems really to be happening. The feeling of a nirvana-like state, after having taken morphine, is implied.

So, we finally can turn and go back: for us it is not Einbahnstrasse, and Portbou is not the final station (figures from Benjamin texts) [11, 12]. At this moment we can see that the underground passage is really a shallow dyke with a thin ceiling - not the real underground (Fig 9). We are not at the end of a serious expedition to the "heart of the Earth". The stairs go in parallel with a mountain, and over the ceiling we can see only a few small stones and poor grass. Again the noisy rumbling of our steps is not a big "return to life": it is rather a painful awakening after a busy night.

When we return back to the top platform, we see that in front of us there is something equivalent to the glass wall at the lower end of the corridor. Previously it was an invisible barrier to fluent waves - temptation to fall into endless water. Here we have smaller stones, a kind of mosaic in the rock, at the end of a metal path. The path is an extension of the direction of stairs, on the whole of 5 or 6 meters.

Dani Karavan has reconstructed the situation of an existential passage in our mind superbly: we walked step by step for a few minutes, followed by the figures from Bejnamin's texts - passages, staircases, lodges, streets, railway stations (Berlin's lodges, Passagenwerk, Einbahnstrasse). He uses spatial and accoustic tools. He engages the wind and protection against the wind - in a warm, "nice" place at the end of the corridor ("lodge with the view on the sea") - to direct our imagination.

The sequence of cadred pictures, and lack of noise with a full view - these are effects known from films. For example, in The Last Temptation of Christ (1988) this effect was used by Martin Scorsese: Christ on the cross sees people around Him, but He cannot hear them. In Portbou we feel the film-like arrangement, the unnatural situation of this place and these conditions ("passage" is like an artificial film scenography) together with the natural, weather factors engaged here by Karavan. We remember, that we are at the "second side" of some kind of "passage", so we know that we are still alive. Thus, at some moment we must leave Benjamin aside. We come back to our life, we meet the stone mosaic as a real, material, and very short-distanced equivalent of

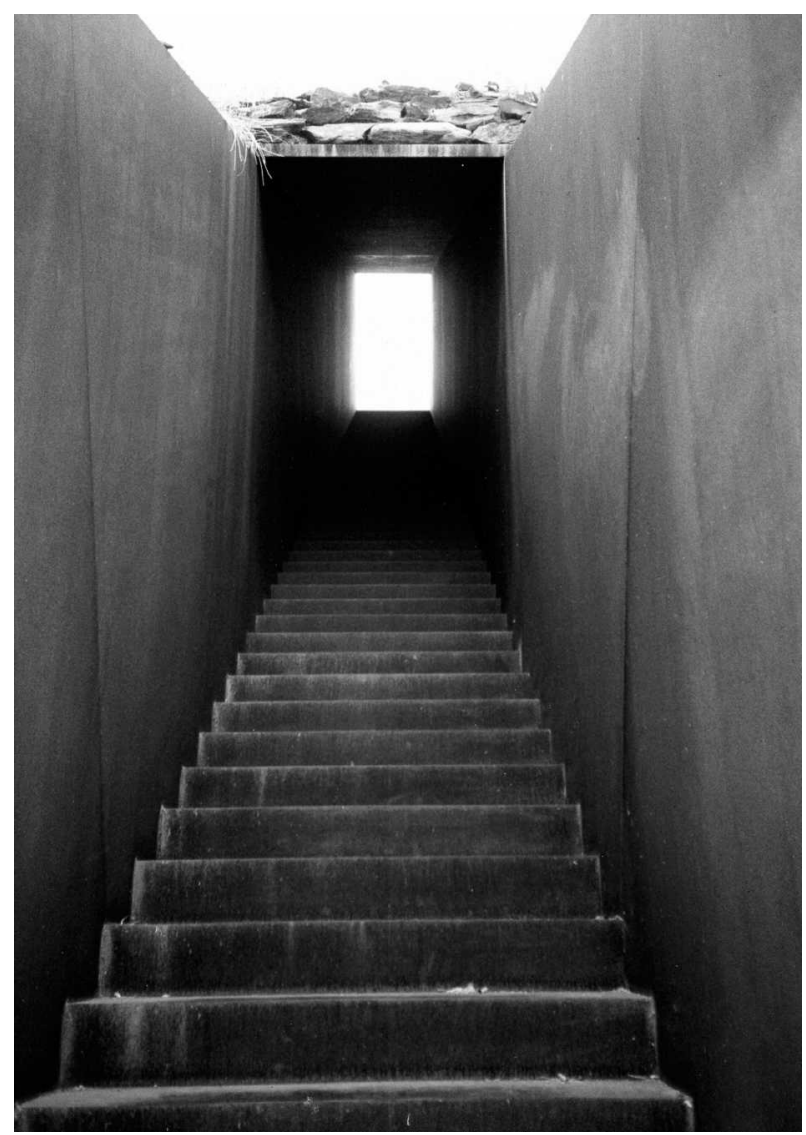

Fig 9. Walter Benjamin Memorial in Portbou, 1993. The tunnel seen upward

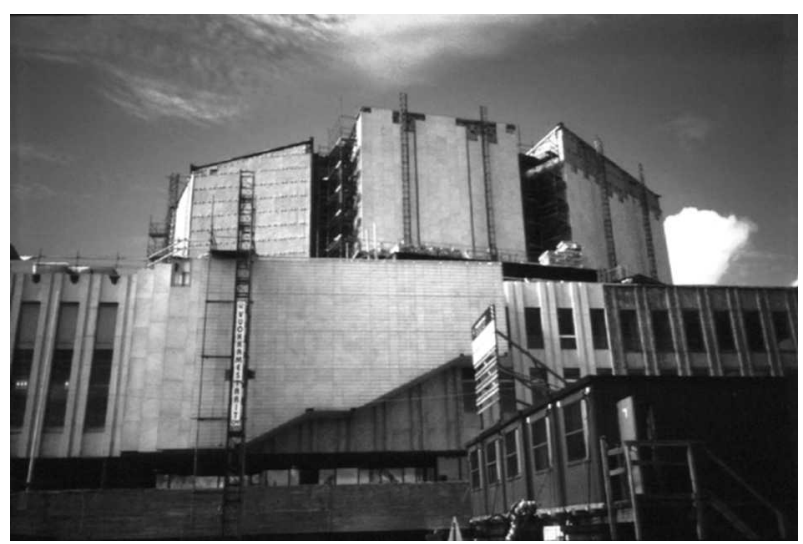

Fig 10. Alvar Aalto, Finlandia talo (Finlandia Congress and Concert Hall in Helsinki, 1969-1975 during changing of marble plates, 1998

our previous unlimited illusions. We realize: it was easy to leave him, it was enough to turn and go upstairs.

Nevertheless, this experience is so strange, uncanny that it returns to memory. It wants to be enriched by the atmosphere of Benjamin's texts. Post factum we come to know that we have "overdosed on morphine" (in the sense of some unity of psychological states), 


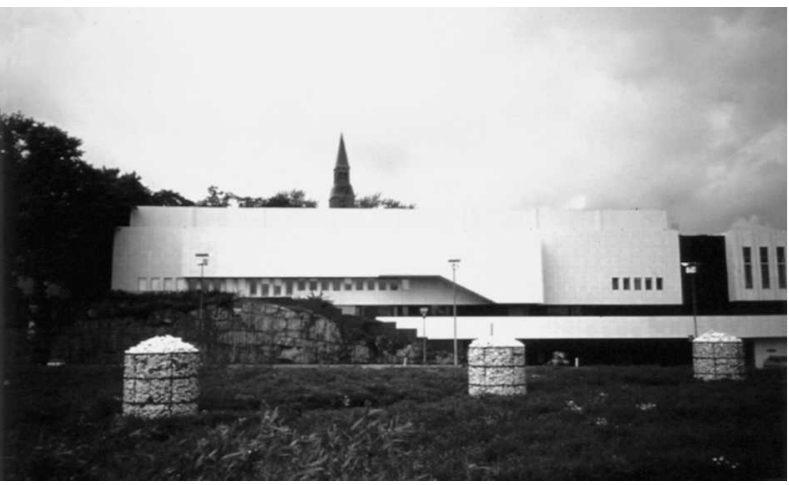

Fig 11. Masaaki Nishi, Harvest - temporal installation in Hesperian Park, in front of the Finlandia talo building, Helsinki, 2000

and that we "died" (in a way). We loose ourselves in this narrow, not so serious dyke, built from thin clads of steel, to generate theatrical rumbles from our steps, in this shallow underground for tourists (and Benjamin readers), in the "innocent" excursion to accompany the another's death...

The last example concerns one of temporal arrangements, executed in 2000 in the Hesperian Park in the centre of Helsinki, as a part of the celebration of the European Capital of Culture. Artists from many countries were invited there. One of them, a Japanese sculptor Masaaki Nishi, found a specific way to emphasize the lapsed time, its meaning and some existential generalization about human beings, nature and architecture [13].

The Finlandia talo (Finlandia Hall) designed by Alvar Aalto and built in 1969-1975 was cladd by carrara marble [14]. After thirty years of outdoor existence the marble plates had become porous and fallen off the wall. In 1998 they were changed, and the methods of its mounting were modernized (Fig 10). After a public discussion it was decided to use carrara marble again according to the original Aalto design, treating the Finlandia talo as a piece of national cultural heritage. (This building and its author were so important for Finnish culture and national ethos, that they were depicted on the 50 Finnish Mark banknote - before the introduction of the Euro).

The crumbled carrara pieces from the Finlandia talo were used by Masaaki Nishi. He placed them into ten huge baskets, made from steel garden netting, and mounted them in the Hesperian garden in front of this building. They look beautiful: light-grey cylinders, with delicate shadows of the netting on a violet heather in front of a high white new wall (Fig 11).

The most impressive moral meaning of this recycling idea was the title of the issue - the Harvest - the time when something comes to maturity, to giving fruit, to the turn of a generation, to replace elderly with novelty, to change the external surface over the permanent, deeper structure, to the eternal rhytms of nature.

This lesson of human behaviour in front of lapsed time is given by the Japanese artist, coming from a culture where continuation and permanent change is treated as a crucial fact of the universe. He used Italian stone, highly valued in cultural terms in the unique prestige of this Finnish public building. These complex factors show a lot about the human condition, not only to Finnish viewers.

The temporal character of this installation and the general contemporary situation of political independence, also in Finland, where previous Soviet pressure also stopped in the 1990s, helps to create a piece about time, the past and future in general, independent from ideological interpretation. Nevertheless, this piece engages a similar strategy of expression of the ethical message, like the above described serious memorials.

\section{Conclusions}

I have shown the path of the turn from the strategy of strong monuments - in a direct, sculptural sense or the monumental buildings with a symbolic role played by the evident, narrative, mimetic, personificated icons of ethical messages - to the "soft" strategy which displays various environmental factors as a medium leading perceivers to a personal, ethical sphere. These last ones have also a serious, intellectual, symbolic potential, and convey to the viewer / participant the experience of being inside the present "problem" - which needs an individual, moral solution - not walking around the visually known representation of the past "problem".

In this "soft" strategy the visual qualities of a piece (monument or architecture) are still important, yet in an indirect way. More important is the relationship between the material and immaterial factors. The ethical message of such spatial arrangements moves the interest of the architectural material's qualities, from its prestige and symbolic ones to evocative and associative ones. Of course, here there is also a danger of the silly, game-like "experienced" (as in Disneyland) accent of the solution.

A parallel problem is the intellectual and emotional competence of viewers. The ones educated on interactive computer games are often uninterested and unable to understand and participate in the classical contemplation of pieces of art (according to Kant's 
formula). Nevertheless, they feel the need for deeper dimmensions within their own existence (for example, the "JPII generation"). So it is the task of architects and creators of these new spaces to emphasize the importance of the message here. I find a balance between activity, a short time of attention paid and quick gratification strategy, on the one hand, and time-consuming classical contemplation, on the other hand, in the formula of "mental interactivity" [10]. The art pieces and spatial relationships described above show the outline of such a formula. Nevertheless, the perspective to generalize this experience to raise it up to a universal level, together with the ethical message, is still possible, and looked forward to by many perceivers / participants / interactors.

\section{References}

1. WINSKOWSKI, P. Architektura jako przestrzenny zapis wartości. O pomnikach i miejscach pamięci. In Aksjologiczne spektrum sztuki, No 3. Estetyczne przestrzenie, J. Tarnowski, P. Kawiecki (eds). Gdańsk: Wydawnictwo Uniwersytetu Gdańskiego, 2005, p. 129-132.

2. GRZESIUK-OLSZEWSKA, I. W trzydziestą rocznicą Międzynarodowego Konkursu na Pomnik Ofiar Oświęcimia. Rzeźba Polska. Rocznik 1986. Orońsko: Centrum Rzeźby Polskiej, 1989, p. 113-118.

3. HANSEN, O. Towards Open Form / Ku Formie Otwartej. Warszawa - Frankfurt am Main: Foksal Gallery Foundation Revolver, 2005, p. 126-131.

4. KĘBŁOWSKI, J. Dzieje sztuki polskiej. Warszawa: Arkady, 1987. $215 \mathrm{p}$.

5. TABORSKA, H. Rozstrzelane kamienie. Polityka, Nr. 30 (2360), Warszawa, 2002, p. 65-67.

6. WINSKOWSKI, P. Architektura jako przestrzenny..., op. cit., p. 132-133.

7. Ibidem, p. 140-142.

8. SCHEURMANN, K. Grenzen, Schwellen, Passagen. Zu Dani Karavans Entwurf eines Gedenkortes für Walter Benjamin. In Für Walter Benjamin. Dokumente, Essays und ein Entwurf. I. K. Scheurmann (eds). Frankfurt am Main: Suhrkanp, 1992, p. 249-264.

9. ZEIDLER-JANISZEWSKA, A. Berlińskie loggie - paryskie pasaźe. In: Pisanie miasta - czytanie miasta. Eadem (ed.). Poznań: Wydawnictwo Fundacji Humaniora, 1997, p. 91-92.

10. WINSKOWSKI, P. Samowyjaśnianie zmylenia w procesie doświadczania przestrzeni. Kultura Wspótczesna, Nr. 1-2 (35-36). Wąrszawa: Narodowe Centrum Kultury, 2003, p. 41-42. English version: Idem. Self-explanation of Deception in Temporal, Spatial Experience. Outis, vol 1. San Diego, CA: Society for Phenomenology and Media, 2004, p. $110-112$.
11. BENJAMIN, W. Aniot Historii. Eseje, szkice, fragmenty. H. Orłowski (ed.), Poznań: Wydawnictwo Poznańskie, 1996.

12. BENJAMIN, W. Einbahnstrasse. Frankfurt am Main: Suhrkamp, $12^{\text {th }}$ ed., $1992\left(1^{\text {st }}\right.$ ed., Berlin, Srnst Rowohlt Verlag, 1928).

13. WINSKOWSKI, P. Architektura jak jętka - jednodniowa. Czas Kultury, Nr. 5/6 (104/105). Poznań: Stowarzyszenie Czasu Kultury, 2001, p. 21-22.

14. SCHILDT, G. Alvar Aalto. A Life's Work-Architecture, Design and Art. Helsinki: Otava, 1994.

\section{ETINIAI VEIKSNIAI ERDVINĖJE APLINKOJE}

\section{P. Winskowski}

Santrauka. Apžvelgiamos kai kurios XX a. antrosios pusès viešumai skirto meno raidos tendencijos, išryškinusios vertybių ir jų ženklinimo erdvinèje aplinkoje slinktis. Apibrèžiami esminiai veiksniai, turèję ịtakos šio laikotarpio viešumai skirto meno raidai: meno kūrinio ribų kitimas, abstraktaus ir konceptualaus meno sklaida, aplinkos svarba šiuolaikiniame mene akcentuojant ne tiek objektus, kiek ju kontekstualius ryšius. Viešumai skirto meno aspektai nagrinejjami aptariant kai kuriuos lenkų sukurtus memorialus, skirtus Antrojo pasaulinio karo aukoms (Vesterplatėje, Gdanske, Treblinkoje, Aušvice-Birkenau) ir kai kuriems vèlesniems tragiškiems visuomeniniams politiniams ivykiams atminti $(1970 \mathrm{~m}$. monumentas Gdanske, taip pat keli užsieniniai pavyzdžiai (Valterio Benjamino memorialas Portbou, Ispanijoje, Masaaki Nishi instaliacija Helsinkyje). Išryškinamas netikètų sprendimų ir alternatyvių iženklinimo formų efektyvumas kuriant itaigius atmintinius ivvykius primenančius kūrinius. Daroma išvada, kad minetos kompozicinès priemonès yra labai reikšmingos rekonstruojant praeityje buvusias situacijas ir kuriant interaktyvią suvokimo aplinką kaip etinio charakterio atspindị.

Reikšminiai žodžiai: viešoji erdvė, erdvinè aplinka, viešumai skirtas menas, meninès instaliacijos, monumentai, etinis pranešimas.

\section{PIOTR WINSKOWSKI}

Ph D, Eng Architect, Adjunct, Chair of Environmental Architecture, Cracow University of Technology, ul. Warszawska 24, PL 31-155 Kraków, Polska. Phone: +4812 6282497

M Arch, 1992. Ph D Arch, 1998. Employed also at the Faculty of Painting, Academy of Fine Arts in Cracow. Publications: author of 2 books, over 60 research papers. Membership: member of Association of Polish Architects (SARP), Society of Friends of Fine Arts in Cracow (TPSP), Polish Association of Aesthetics (PTE). Research interests: theory of architecture, modern and postmodern architecture, relationship between architecture and other spatial arts. 